\title{
Isolated Leptomeningeal Carcinomatosis in a Patient with Newly Diagnosed Gastric Cancer
}

\section{Yeni Tanı Mide Karsinomlu Hastada İzole Leptomeningeal Karsinomatoz}

\author{
Tahsin Özatlı, Öznur Bal, Burçin Budakoğlu, Ahmet Şiyar Ekinci, Onur Eşbah, Berna Öksüzoğlu
}

Dr. A. Y. Ankara Onkoloji Eğitim Ve Araştırma Hastanesi, Tıbbi Onkoloji Kliniği, Ankara, Türkiye

Doi: $10.5505 /$ aot.2013.09797

\section{ÖZET}

Kırküç yaşında erkek karın ağrısı ve hematemez ile kabul edildi. Hasta endoskopik biyopsi ile mide karsinomu tanıs1 aldı ve total gastrektomi yapıldı. Gastrektominin 6.gününde, baş ağrısı ve çift görme yakınması oldu. Beyin manyetik rezonans görüntülemede bilateral serebellar hemisferde kontrast artışı ve leptomeningeal kalınlaşma gözlendi. Birinci serebrospinal sıvı incelemesinde malign hücre gözlenmedi. İkinci incelemede malign hücre şüphesi içermekteydi. Hastanın leptomeningeal karsinomatosis ile uyumlu klinik ve radyolojik değerlendirmelerinden dolayı, intratekal kemoterpi uygulandı ve hastanın nörolojik semptomları düzeldi.

Anahtar Kelimeler: Mide Karsinomu; Leptomeningeal Karsinomatoz; İntratekal Kemoterapi

\section{ABSTRACT}

A 43 year-old man admitted with abdominal pain and hematemesis. He diagnosed with gastric cancer by endoscopic biopsy and total gastrectomy was carried out. On the sixth day of gastrectomy he complained about headache and diplopia. Magnetic resonance imaging of the brain showed leptomeningeal thickening and contrast enhancement of bilateral cerebellar hemisphere. First cerebrospinal fluid examination revealed no malignant cells, the second one was suspicious for malignant cells. Because of the radiological and clinical evaluation of the patient compatible with the Leptomeningeal Carcinomatosis, intrathecal chemotherapy was performed and his neurological symptoms were improved.

Key words: Gastric Cancer; Leptomeningeal Carcinomatosis; Intrathecal Chemotherapy

\section{Introduction}

Leptomeningeal carcinomatosis (LMC), the diffuse infiltration of the meninges by the malignant cells, is one of the most important complications of cancers and seen mostly in breast, lung cancer and malign melanoma $(1,2)$. LMC is an atypical metastatic side of gastric cancer (GC) with an incidence of almost $0.06 \%$ (2) .

We report a patient who was accepted to our clinic because of diplopia and headache on the sixth day of gastrectomy.

\section{Case Report}

A 43 year-old man referring to a center with abdominal pain and hematemesis. $\mathrm{He}$ diagnosed with gastric cancer by endoscopic biopsy in November 2011. Thoracoabdominal computarized tomography (CT) showed that gastric wall thickening and there was no metastatic lesions. Histological examination of gastrectomy material revealed a signet ring cell

Adressforcorrespondence: Uzm. Dr. Tahsin Özatlı

e-mali: onkologozatli@ hotmail.com

Available at www.actaoncologicaturcica.com

Copyright @Ankara Onkoloji Hastanesi adenocarcinoma staged as T4aN3aM0. On the sixth day of gastrectomy he complained about headache and diplopia. magnetic resonance imaging (MRI) of the brain showed leptomeningeal thickening and contrast enhancement of bilateral cerebellar hemisphere. First cerebrospinal fluid (CSF) examination revealed no malignant cells, the second one was suspicious for malignant cells. Despite the results of CSF examinations, because of the radiological and clinical evaluation of the patient compatible with the LMC, intrathecal (IT) chemotherapy was performed two times with methotrexate. In the follow up, treatment of patient was postponed because of acute abdomen due to anastomotic leakage and he had to be transferred to general surgical service. After intrathecal chemotherapy his neurological complaints have regressed. He has given eight cycles chemotherapy of cointaining docetaxel, cisplatin, 5-flourouracil and followed up progression free after 10 months of initial diagnosis. 


\section{Discussion}

LMC most frequently caused by breast (12$34 \%)$, lung (14-29\%), melanoma (17-25\%) (2). Adenocarcinoma is the most common histologic type in patients with LMC. It is extremely rare in GC and histopatological type is signet ring cell carcinoma in most cases $(1,3,4)$. LMC is usually seen in advanced stages of cancer (3). In addition to brain metastasis, multiple metastatic lesions including the liver, lungs and bone may be seen (5). The median time between diagnosis of GC and LMC is approximately 12 months (6). In our case, the shorter interval may be explained with the presence of asymptomatic microscopic disease at the time of the operation.

LMC may lead to multifocal neurological deficits, which may be associated with infiltration of cranial and spinal nerve roots, direct invasion of the brain or spinal cord or some combination of these factors. In our case, the patient's first neurologic symptom was diplopia following headache. Radiological imaging techniques play an important role in the diagnosis of LMC. The sensitivity of cranial MRI in the diagnosis of LMC had been reported as between $65-75 \%$ in the literature (6). The definitive diagnosis of LMC can only be made by documenting the presence of malignant cells in the CSF. However, in one-third of the patients, CSF cytology is not diagnostic (7). Wasserstrom et al. reported that the first CSF sampling has a diagnostic sensitivity of $54 \%$ and with repeated samplings, this ratio increases up to $91 \%$ (1). In our case, the first CSF sampling was negative and the second one was suspicious for malignant cells. Because of the radiological and clinical evaluation compatible with the LMC, IT treatment was performed.

The prognosis of LMC is poor and after the diagnosis median overall survival (OS) is 4-6 weeks in untreated patients. Median OS may be increased to 4-6 months with aggressive treatment in some cases $(8,9)$. Standard therapy involves IT chemotherapy in combination with radiotherapy (RT) (10). However, efficacy of IT chemotherapy is controversial because of uncertain survival benefit $(10,11)$. Methotrexate remains the most frequently used drug for IT administration, despite limited success and serious toxicity
(12). In our patient with ECOG 2-3 score at the treatment; only chemotherapy was administered because of RT may increase the side effects. The independent prognostic factor for survival was cytologic negative conversion by IT chemotherapy (13). In our patient, because of acute abdomen we have not able to evaluate response of treatment via CSF cytology but we observed clinical response.

In conclusion, $\mathrm{LMC}$ is a rare entity and have a poor prognosis. Treatment of LMC with chemotherapy and RT is rarely curative and tends to be mostly palliative. Newly onset neurological symptoms in a patient, even nonmetastatic, should alert the physician for central nervous system involvement.

\section{Conflict of Interest: None}

\section{References}

1. Wasserstrom WR, Glass JP, Posner JB. Diagnosis and treatment of leptomeningeal metastases from solid tumors. Experience with 90 patients. Cancer 1982;49:759-72

2. Grossman SA, Krabak MJ. Leptomeningeal carcinomatosis. Cancer Treat Rev 1999;25:103-9

3. Lee JL, Kang YK, Kim TW et al. Leptomeningeal carcinomatosis in gastric cancer. J Neurooncol 2004;66:167-74

4. Kim M. Intracranial involvement by metastatic gastric carcinoma. J Neurooncol 1999;43:59-62

5. Aiello-Laws L, Rutledge DN. Management of adult patients receiving intraventriculer chemotherapy for the treatment of leptomeningeal metastasis. Clin J Oncol Nurs 2008;12:429-435

6. Lisenko Y, Kumar AJ, Yao J, et al. Leptomeningeal carcinomatosis orginating from gastric cancer. Am J Clin Oncol 2003;26:165-70

7. Rudnicka H, Niwinska A, Gruszfelt A, Pienkowski T. Diagnosis and treatment of carcinoid meningitis: a challenge to the neurologist and oncologist. Neurol Neurochir Pol 2003;37:811-24

8. Kim L, Glantz M. Neoplastic meningitis. Curr Treat Options Oncol 2001;2:517-27

9. Balm M, Hammack J. Leptomeningeal carcinomatosis. Presenting features and prognostic factors. Arch Neurol 1996;53:626-32

10. Giannone L, Greco FA, Hainsworth JD. Combination intraventricular chemotherapy for meningeal neoplasia. J Clin Oncol 1986;4:68-73

11. Hitchins RN, Bell DR, Woods RL, Levi JA. A prospective randomized trial of single-agent versus combination chemotherapy in meningeal carcinomatosis. J Clin Oncol 1987;5:1655-62

12. Bleyer WA, Drake JC, Chabner BA. Neurotoxicity and elevated cerebrospinal-fluid methotrexate concentration in meningeal leukemia. N Engl J Med 1973;289:770-3

13. Oh SY, Lee SJ, Lee J, et al. Gastric Leptomeningeal carcinomatosis: multi-center retrospective analysis of 54 cases. World J Gastroenterol 2009;15:5086-90 
